\title{
Self-ear Cleaning Practices and Hazards Among Undergraduates of a Private University in Nigeria
}

\section{James E Tobih ${ }^{1}$, Theophilus O Esan ${ }^{2 *}$, Deborah T Esan ${ }^{3}$ and Ifeoluwa J Ojumu $^{4}$}

${ }^{1}$ Associate Professor and Head of Otorhinolaryngology Department, Ladoke

Akintola University of Technology/Teaching Hospital, Osogbo, Nigeria

${ }^{2}$ Otorhinolaryngology Department, Federal Teaching Hospital, Ido-Ekiti, Nigeria

${ }^{3}$ Associate Professor of Nursing, Department of Nursing Science, Afe Babalola

University, Ado-Ekiti, Nigeria

${ }^{4}$ Department of Nursing Sciences, Afe Babalola University, Ado-Ekiti, Nigeria

*Corresponding Author: Theophilus O Esan, Otorhinolaryngology Department,

Federal Teaching Hospital, Ido-Ekiti, Nigeria.
Received: September 23, 2021

Published: November 26, 2021

(C) All rights are reserved by Theophilus 0

Esan., et al.

\begin{abstract}
Background: One of the commonest infections of the ear is that of the external ear canal which is most susceptible than any other part of the ear because it opens directly with the outside unlike the middle and inner ear that are enclosed within. In addition, it admits readily any object without any reflex objection like the eye hence it is most vulnerable to all kinds of assault from self and externals yet infections in the external ear if not well managed can spread to middle ear, inner ear and even brain. The consequences may portend high mortality and morbidity with severe hearing disability. This is the reason for undertaking this research reviewing the age long practice of self-ear cleaning and the attendant dangers.
\end{abstract}

Methodology: A descriptive cross-sectional design was employed to assess the self-ear-cleaning practices among undergraduates of a Private University in Nigeria. Semi-structured, pre-tested adapted questionnaires was used for data collection. These questionnaires were administered to all willing students who have given their prior consent after permission has been gotten from the Ethics and Research Committee of the Institution.

Result: The result showed that majority (71.3\%) of the respondents are female and are Christians (88\%).

Findings from this study revealed that almost all (98\%) practices self-ear cleaning regularly excluding only $4 \%$ who does not clean the ear at all. Result also showed that they all clean their ears with all kinds of objects but majority with cotton buds, some even with pen cover and metallic hairpin. Furthermore many of the respondents have suffered from complications like ear pain 39(38.6\%), bleeding 15(14.9\%), and itching 23(22.8\%). The study showed that many believed self-ear cleaning is safe and hygienic and never associated with dangers.

Conclusion: Our conclusion is that the prevalent rate of self-ear cleaning among undergraduate students of a Private University is very high with majority suffering various complications arising from this practice. The practice cuts across all students at all levels of academic study, disciplines, ethnic groups and religions.

Keywords: Self-ear Cleaning; Practice; Hazards; Private University; Nigeria

\section{Introduction}

Ear as one of the sensory organ serves the function of cochlear (Hearing) and vestibular (balance). It is made up of three parts - the external ear consisting of the pinna (auricle) and the external auditory canal, the middle ear consisting of the tympanic membrane and the ossicles and the inner ear consisting of the cochlea, 
the vestibule, and the nerves. The external auditory canal cleanses itself because naturally the epithelial lining shed off outwardly regularly with all other trapped debris hence no external cleaning is needed except when the canal integrity is already compromised by self-cleaning practice [1]. While adequate amount of cerumen is necessary in order to avoid ear infections, excess of it may result in impaction which may cause pain, hearing loss or even dizziness. People engaged in self-ear practices due to wax, dirt and itchiness [2].

The knowledge and awareness of ear care practice however is still lacking among the general populace. Non -hygienic individual behaviours and habits like inserting all kinds of unsterile objects into the ear canal is still prevalent. Lack of proper ear care may lead to many diseases and its complications [3].

The practice of self-ear cleaning is age long and global and cut across gender and age. Sometimes it stems from culture and tradition but most often it is reflex resulting from some tingling sensation in the ear canal. It involves the insertion of objects into the ear canal and it is widespread practice that has the potential to compromise its integrity as a natural, self-cleansing mechanism, and a risk factor for possible injuries [4]. In developing regions, the morbidity and mortality associated with ear diseases and injuries remain a significant but neglected public health problem [4]. It is found to be commoner among those who perceived the practice to being beneficial and thought was useful in cleaning the ear of wax, dirt and debris, itchiness and to soothe the ear. This is confirmed by the study by $[1,2,5]$. emphasize the need for medical education of health workers and health education for the general public to improve their understanding of caring for the ear and the dangers of self-ear cleaning. Cleaning practices are largely preventable if the public is educated appropriately in the area of self-ear cleaning and its associated risk factors.

It is believed that the insertion of objects into the ear canal is for ear hygiene and that it is necessary to remove the excess cerumen or that cerumen is perceived as a cosmetic nuisance. It has been reported that most individuals consider cerumen as dirt and harmful to the human. Otitis externa, cerumen impaction, and injuries to the ear are thought to be associated with self-ear-cleaning [6]. Medical advice not to clean the ears is not widely known. Instead, the erroneous perception that self-ear-cleaning is beneficial is common [7].
Major reasons for self-ear cleaning were to remove ear wax inform of personal hygiene and because ear wax was considered as a dirt from the ear. Other reasons for self-ear cleaning includes feeling of ear discomfort, earache, hearing impairment and itching. There are various object used for self-ear cleaning and they include cotton bud, key, soapy water, feathers, stick, pen cover, finger and so on.

The complications of self-ear cleaning are ear trauma, traumatic tympanic membrane perforation, and impacted object, and inflammation, otitis external from bacterial and fungal infection. Other complications includes interferes with the self-cleansing function of the external auditory canal which may lead to accumulation and subsequently ear wax impaction. Self-ear cleaning also leads to weakening of the external auditory canals local defence against bacterial and fungal infections. The risk is even greater when this is done as a blind procedure without direct inspection of the ear canal using objects not designed to remove wax and foreign bodies in the ear, such as cotton buds and loose tip cotton swabs, feathers, sticks and a variety of other objects. According to Afolabi., et al. this habit needs to be discouraged, as it is a slow otologic poison, that can lead to various risks [1]. Other studies have alluded to gender differences in the frequency of ear cleaning, with more females cleaning more frequently than males. However, both the lack of public awareness regarding the availability of treatment options and the lack of active practice by health professionals has resulted in an increase in self-ear cleaning practice also, there is paucity of literature on self-ear cleaning in low income countries. This practice is common in young adult usually between ages of 21 to 30 years. Wax in the ear canal causes "a sizeable burden" on the healthcare resources of a country [8].

Olajide., et al. noted that people did not have information about the dangers of cotton bud usage in the ear and had poor knowledge about the ear as a self-cleansing mechanism [9]. Cotton bud use is unnecessary and can cause some dangerous complications [10]. Young educated adults do engage in self-ear cleaning, which can potentially increase the risk of ear injury and ear related symptoms. In a study conducted by Alshehri., et al. Academic year of students had no significant effect on participant opinions about the beneficial or non-beneficial role of self-ear-cleaning [11].

It is important that cerumen management be done by qualified personnel, as removal by inexperienced persons can cause damage to the ear. It is usually unnecessary to clean the ear canal, as exces- 
sive cleaning increases humidity and softens the ear canal lining, which can result in infection and irritation of the ear that can cause changes to the skin lining and thereby impair normal functioning.

Clearly, there is a need for more education. There is a general belief in our society that there is nothing wrong with using cotton buds, and this worsens the habit of using cotton buds simply to alleviate symptoms such as itching, removal of dirt and perhaps even with claims of perceived benefits [1]. This study therefore seeks to explore self-ear cleaning practices among undergraduates of a Private University in Nigeria.

\section{Materials and Methods}

A descriptive design was employed using quantitative approach to assess the self-ear-cleaning practices among undergraduates of Afe Babalola University in Ekiti state. The study was conducted between January and February 2021. Semi-structured, adapted questionnaires that were made as simple and clear as possible, with the targeted sections and questions. The researcher recruited undergraduates' students of Afe Babalola University, Ado-Ekiti. Each participant was informed about the purpose of the study and guidelines for the completion of the questionnaire was explained to the participants and asked to tick where appropriate. Sufficient time was given to allow for successful filling of questionnaire before collection. Data was analysed using Statistical Package for Social Sciences (SPSS) version 25. Data were presented in frequencies and percentages.

\section{Results}

A total of 101 respondents were recruited and all the 101respondents completed the questionnaires and had adequate data for analysis. This translates to a response rate of $100 \%$.

Table 1 revealed the distribution of respondents according to socio-demographic characteristics. Most of the respondents (71.3\%) are female, majority (88.1\%) are Christian, most of the respondents $(26.7 \%)$ are in Medical Health Sciences College with $26.7 \%$ being nursing students, and are in 400 level. Table 2 revealed the distribution of respondents according to self-ear cleaning practices. Most of the respondents (29.7\%) use cotton bud to clean your ears (may select more than one), more than half (58.4\%) once in a while clean their ears, majority (72\%) said their parent clean their ears once in a while (34.7\%), majority $(82.2 \%)$ said their siblings clean their ears Regularly and Once in a while

in $39.6 \%$ of the respondents. Table 3 revealed the distribution of respondents according to associated risk of ear injuries and ear related symptoms, majority (62.4\%) have heard about the dangers associated with cotton bud, but few (25.7\%) have suffered complications on cotton bud, feathers etc. usage, majority (38.6\%) have experienced ear pain, few (33.7\%) have ever experienced, majority (56.4\%) have never inserted a foreign body i.e. beads in their ears, few (35.6\%) have heard of otitis external, (19.8\%) have ever been diagnosed with otitis externa, majority (47.5\%) have otitis media. Table 4 revealed the distribution of respondents according to knowledge on practices of self-ear cleaning, majority (77.2\%) said wax is a Dirty substance, most of the respondents (25.7\%) said the present of wax is alright as long as it doesn't block up the ears, majority. Table 5 revealed the distribution of respondents according to attitude and practices towards self-cleaning. More than half 51 (50.5\%) strongly agreed that Cotton bud should be used to clean the ears, more than half 58 (57.4\%) agreed that Cotton buds are good for removing ear wax, majority 75 (74.3\%) strongly agreed that best not to clean the ears using a cleaning aid, and most of the respondents 35 (34.7\%) could not decide if Cotton bud can cause a lot of complications (e.g. bleeding, infection, wax impaction).

\begin{tabular}{|c|c|c|c|}
\hline Variables & Categories & Respondent(n=101) & (\%) \\
\hline \multirow[t]{2}{*}{ Gender } & Male & 29 & 28.7 \\
\hline & Female & 72 & 71.3 \\
\hline \multirow[t]{3}{*}{ Age } & $16-20$ & 32 & 31.7 \\
\hline & $21-25$ & 35 & 34.7 \\
\hline & $26-30$ & 34 & 33.7 \\
\hline \multirow[t]{2}{*}{ Religion } & Christianity & 89 & 88.1 \\
\hline & Muslim & 12 & 11.9 \\
\hline \multirow[t]{5}{*}{ College } & MHS & 27 & 26.7 \\
\hline & Law & 20 & 19.8 \\
\hline & Engineering & 26 & 25.7 \\
\hline & Sciences & 20 & 19.8 \\
\hline & SMS & 8 & 7.9 \\
\hline \multirow[t]{7}{*}{ Department } & Nursing & 27 & 26.7 \\
\hline & MBBS & 23 & 22.8 \\
\hline & Mls & 9 & 8.9 \\
\hline & Biochemistry & 9 & 8.9 \\
\hline & Civil Eng. & 9 & 8.9 \\
\hline & Pharmacy & 15 & 14.9 \\
\hline & Others & 9 & 8.9 \\
\hline
\end{tabular}

Citation: Theophilus O Esan., et al. "Self-ear Cleaning Practices and Hazards Among Undergraduates of a Private University in Nigeria". Acta Scientific Medical Sciences 5.12 (2021): 151-157. 


\begin{tabular}{|c|c|c|c|}
\hline Level & 100 & 6 & 5.9 \\
\hline & 200 & 11 & 10.9 \\
\hline & 300 & 22 & 21.8 \\
\hline & 400 & 38 & 37.6 \\
\hline & 500 & 18 & 17.8 \\
\hline & 600 & 6 & 5.9 \\
\hline & Total & 101 & 100.0 \\
\hline
\end{tabular}

Table 1: Distribution of respondents according to socio-demographic characteristics.

\begin{tabular}{|l|c|c|c|}
\hline Variables & Categories & (n=101) & (\%) \\
\hline $\begin{array}{l}\text { Do your parents } \\
\text { clean their ears }\end{array}$ & Nes & 72 & 71.3 \\
\hline & Weekly & 29 & 28.7 \\
\hline $\begin{array}{l}\text { How often do } \\
\text { they clean their } \\
\text { ears }\end{array}$ & Never & 26 & 25.7 \\
\hline & Yes & 35 & 34.7 \\
\hline $\begin{array}{l}\text { Once in a while } \\
\text { days intervals }\end{array}$ & 23 & 22.8 \\
\hline clean their ears & No & 18 & 16.8 \\
\hline $\begin{array}{l}\text { How often do } \\
\text { they clean it }\end{array}$ & $\begin{array}{c}\text { Regularly Once in a } \\
\text { while }\end{array}$ & 40 & 82.2 \\
\hline & 7 days intervals & 33 & 32.7 \\
\hline & Never & 28 & 27.7 \\
\hline & Total & 101 & 100.0 \\
\hline
\end{tabular}

Table 2: Distribution of respondents according to self-ear cleaning practices.

\begin{tabular}{|l|c|c|c|}
\hline Variables & Categories & (n = 101) & (\%) \\
\hline $\begin{array}{l}\text { Have you heard about } \\
\text { the dangers associated } \\
\text { with cotton bud }\end{array}$ & Yes & 63 & 62.4 \\
\hline $\begin{array}{l}\text { Have you suffered } \\
\text { complications on } \\
\text { cotton bud, feathers } \\
\text { etc. usage }\end{array}$ & Yes & 26 & 25.7 \\
\hline & No & 75 & 74.3 \\
\hline
\end{tabular}

\begin{tabular}{|c|c|c|c|}
\hline $\begin{array}{l}\text { Have you ever } \\
\text { experienced any one } \\
\text { of these }\end{array}$ & Ear pain & 39 & 38.6 \\
\hline & Itchiness & 23 & 22.8 \\
\hline & Bleeding & 15 & 14.9 \\
\hline & Other problems & 8 & 7.9 \\
\hline & Never & 16 & 15.8 \\
\hline \multirow{2}{*}{$\begin{array}{l}\text { Have you ever } \\
\text { experienced any one } \\
\text { of these }\end{array}$} & Yes & 34 & 33.7 \\
\hline & No & 67 & 66.3 \\
\hline \multirow{3}{*}{$\begin{array}{l}\text { Have you ever inserted } \\
\text { a foreign body i.e. } \\
\text { beads in your ears }\end{array}$} & Yes & 18 & 17.8 \\
\hline & No & 26 & 25.7 \\
\hline & Never & 57 & 56.4 \\
\hline \multirow[t]{2}{*}{$\begin{array}{l}\text { Have you heard of } \\
\text { otitis external }\end{array}$} & Yes & 36 & 35.6 \\
\hline & No & 65 & 64.4 \\
\hline \multirow{3}{*}{$\begin{array}{l}\text { Have you ever been } \\
\text { diagnosed with } \\
\text { otitis externa }\end{array}$} & Yes & 20 & 19.8 \\
\hline & No & 23 & 22.8 \\
\hline & Never & 58 & 57.4 \\
\hline \multirow{2}{*}{$\begin{array}{l}\text { Have you ever been } \\
\text { treated for any ear } \\
\text { infection }\end{array}$} & Yes & 48 & 47.5 \\
\hline & No & 53 & 52.5 \\
\hline \multirow[t]{4}{*}{ which one } & Otalgia & 21 & 20.8 \\
\hline & Otitis external & 21 & 20.8 \\
\hline & Otitis media & 6 & 5.9 \\
\hline & Total & 48 & 47.5 \\
\hline Total & & 101 & 100.0 \\
\hline
\end{tabular}

Table 3: Distribution of respondents according to associated risk of ear injuries and ear related symptoms.

\begin{tabular}{|l|c|c|c|}
\hline Variables & Categories & (n=101) & (\%) \\
\hline $\begin{array}{l}\text { What is wax (choose } \\
\text { one answer) }\end{array}$ & Dirty substance & 78 & 77.2 \\
\hline & Normal product & 14 & 13.9 \\
\hline Don't know & 9 & 8.9 \\
\hline $\begin{array}{l}\text { What do you think } \\
\text { of the presence of } \\
\text { wax in the ear }\end{array}$ & $\begin{array}{c}\text { Dirty and needs to be } \\
\text { removed }\end{array}$ & 24 & 23.8 \\
\hline
\end{tabular}




\begin{tabular}{|c|c|c|c|}
\hline & $\begin{array}{c}\text { Dirty but can be left } \\
\text { alone }\end{array}$ & 22 & 21.8 \\
\hline & $\begin{array}{l}\text { It's alright as long as it } \\
\text { doesn't block up the ears }\end{array}$ & 26 & 25.7 \\
\hline & $\begin{array}{l}\text { It's alright can be left } \\
\text { alone to serve its } \\
\text { functions }\end{array}$ & 20 & 19.8 \\
\hline & Normal & 9 & 8.9 \\
\hline \multirow{4}{*}{$\begin{array}{l}\text { how do you know } \\
\text { when to clean your } \\
\text { ears }\end{array}$} & When it itches & 32 & 31.7 \\
\hline & $\begin{array}{l}\text { Irritation when ears are } \\
\text { blocked }\end{array}$ & 35 & 34.7 \\
\hline & After shower or bath & 25 & 24.8 \\
\hline & $\begin{array}{l}\text { When convenient to do } \\
\text { so (e.g. while watching } \\
\text { TV, pressing phone etc.) }\end{array}$ & 9 & 8.9 \\
\hline \multirow[t]{2}{*}{$\begin{array}{l}\text { Have you ever heard } \\
\text { of cerumen }\end{array}$} & Yes & 55 & 54.5 \\
\hline & No & 46 & 45.5 \\
\hline \multirow[t]{5}{*}{$\begin{array}{l}\text { If yes what is } \\
\text { cerumen }\end{array}$} & Yellow waxy substance & 20 & 19.8 \\
\hline & $\begin{array}{c}\text { Something yellowish in } \\
\text { the ear }\end{array}$ & 18 & 17.8 \\
\hline & $\begin{array}{c}\text { Sticky substance in the } \\
\text { ear }\end{array}$ & 11 & 10.9 \\
\hline & $\begin{array}{c}\text { A brown or grey } \\
\text { substance secreted in the } \\
\text { ear canal of humans or } \\
\text { mammals }\end{array}$ & 6 & 5.9 \\
\hline & Total & 55 & 54.5 \\
\hline Total & & 101 & 100.0 \\
\hline
\end{tabular}

Table 4: Distribution of respondents according to knowledge on practices of self-ear cleaning.

\begin{tabular}{|l|c|c|c|c|}
\hline Variables & \multicolumn{4}{|c|}{ Categories } \\
\hline & $\begin{array}{c}\text { Strongly } \\
\text { Agree (\%) }\end{array}$ & Agreed (\%) & $\begin{array}{c}\text { Disagree } \\
\text { (\%) }\end{array}$ & $\begin{array}{c}\text { Strongly } \\
\text { Disagree } \\
(\%)\end{array}$ \\
\hline $\begin{array}{l}\text { Cotton bud } \\
\text { should be used to } \\
\text { clean the ears }\end{array}$ & $51(50.5 \%)$ & $19(18.8 \%)$ & $17(16.8 \%)$ & $\begin{array}{c}14 \\
(13.9 \%)\end{array}$ \\
\hline $\begin{array}{l}\text { Cotton buds are } \\
\text { good for } \\
\text { removing ear wax }\end{array}$ & $9(8.9 \%)$ & $58(57.4 \%)$ & $17(16.8 \%)$ & $\begin{array}{c}17 \\
(16.8 \%)\end{array}$ \\
\hline
\end{tabular}

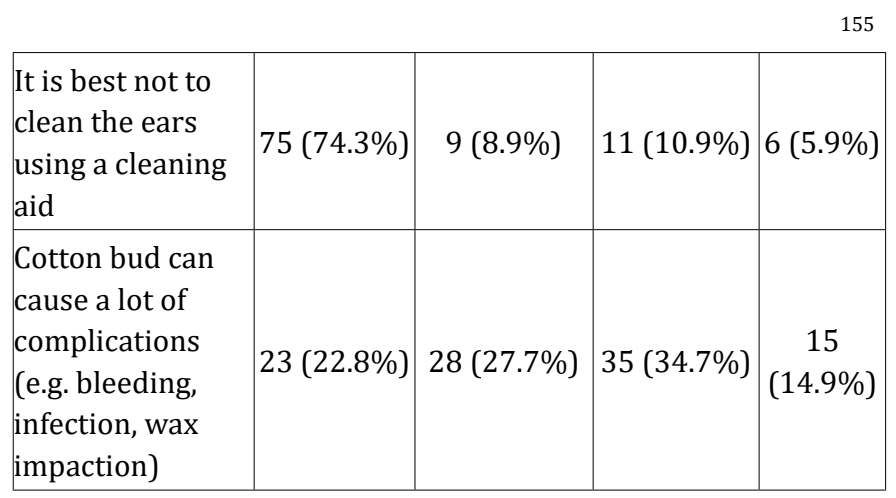

Table 5: Distribution of respondents according to attitude and practices towards self-cleaning.

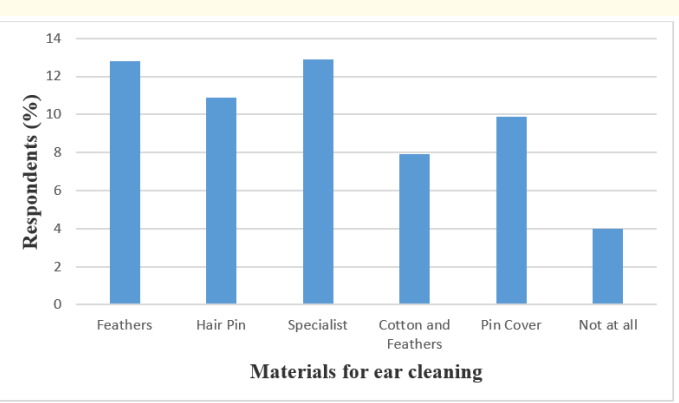

Figure 1: Materials used by respondents in cleaning ear.

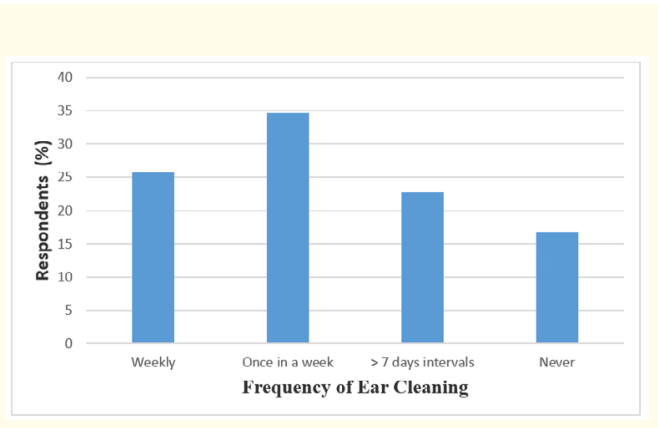

Figure 2: Frequency of ear cleaning among respondents.

\section{Discussion}

Socio-demographic characteristics of the respondents show $72(71.3 \%)$ are females and 29(28.7) are males. Higher proportion of the respondents fell into the age range $21-30(69 \%)$ and 89 (88.1\%) were Christians while 12(11.9) were Muslims. Findings in respect of gender and religion were same as that of Adebiji., et al. 
[12] but the age range in their study differs from ours, where majority were between ages 30 to 40 years. This may due to the fact that their own were patients sample involving mainly adults, workers, artesian and mostly low education but our study was strictly among University undergraduates. Similarity in gender and religion may be as a result of the fact that the same south-west region of Nigeria was used though different location. Amutta. 2016 [13] also found that self-ear cleaning was widely practiced in a community based study, in all groups in Nigeria, being highest amongst young adults 21-30 years, and higher in university graduates than any other graduates. Oladeji., et al. [5] also found it to be very high $(94 \%)$ in health workers, which is of concern, considering that they should be practicing safe and healthy ear care methods. Another study conducted with physicians in Nigeria showed that $76.3 \%$ of physicians practiced self-ear cleaning, mainly for reasons of hygiene [4]. The peak age found may also be explained by the fact that this age majority are conscious of the aesthetes of their body and its cleanliness and ear is perceived to be one of the part that needs to be clean well to hear well. The study also showed that all the levels of academic study and disciplines were involved except those excluded.

In our study regarding self-ear cleaning practices we found high prevalence of 76.1\%(84 respondents) engaged in self-ear cleaning, Only $13(12.9 \%)$ sought a doctor for cleaning while only 4 abstain from self-ear cleaning completely It cuts across tribes and religion. The commonest material used is the cotton bud (29.7\%), this is also the finding in many studies $[5,9,12]$. Others still uses feathers, hairpin, pen cover, finger, tip of blanket, key, broom stick.

Our study showed a high percentage have good knowledge about some dangers of cleaning the ear but that does not translate to caution. It is significant in this study that many have suffered various complications from ear pain (38.6\%), itching (22.8\%) and bleeding (14.9\%). Furthermore 20(19.8\%) have been diagnosed at one time or the other with otitis externa while 48 (47.5\%) have been diagnosed as Otitis media and other forms of ear infection. This is in line with other studies where complications like ear discharge, impacted foreign body, tinnitus, lacerations, perforated tympanic membranes, that necessitated tympanoplasty $[5,12]$. Adebiji., et al. [12] and Afolabi [1] also found that the frequent use of cotton buds is associated with some ear diseases such as wax impaction, ear infection, facial nerve palsy, dizziness, perforation of the ear drum, perilymphatic fistula, trauma to the ear canal, and deafness The knowledge and awareness of ear care practice in rela- tion to wax removal, the main object of self-ear cleaning however is still lacking. Non-hygienic individual behaviors and habits like inserting unsterile foreign objects still prevalent [13].

This study also found a high percentage of respondents have wrong attitudes towards ear care. 51 (50.5\%) strongly agreed that Cotton bud should be used to clean the ears, and 58 (57.4\%) agreed that Cotton buds are good for removing ear wax while a high percentage $35(34.7 \%)$ does not know the hazards associated with the use of cotton buds. This also agrees with the findings of Olajide., et al. [9], who found that there is poor awareness about the risks associated with self-ear cleaning as well as the function of wax within the ear. (Oladeji., et al. [16] emphasize the need for medical education of health workers and health education for the general public to improve their understanding of caring for the ear and the dangers of self-ear cleaning. Ear care is a part of social cleanliness. It may not demand much care but proper and adequate attention is essential to protect the optimal functions 2020) [3]. Ear wax is a normal, healthy substance with a number of functions. It cleans, lubricates and protects the lining of human ears by trapping dirt and repelling water. It usually breaks down naturally and falls out of the ears in tiny flakes [14].

\section{Conclusion}

This study has found that majority of young adults indulged in this practice of ear- self-cleaning with imminent dangers which may bring huge economic burden to the individual or family or community with devastating morbidity of hearing impairment if adequate intervention is not promptly instituted. There is gross under and misinformation about this practice hence there is urgent need for immediate aggressive health education to arrest the tide of the practice, which should commence from elementary to higher institutions and the society at large.

\section{Ethical Consideration}

Ethical approval to conduct this research was obtained from Ethics and Research Committee of Afe Babalola University, AdoEkiti, Nigeria. Informed consent was also obtained from respondents.

\section{Limitation}

- $\quad$ Some questionnaire got lost and had to be reprinted for data collection.

- There were difficulty of collection of data from some students due to class schedule. 


\section{Financial Support and Sponsorship}

Nil.

\section{Conflict of Interest}

There is no conflict of interest.

\section{Bibliography}

1. Afolabi A 0., et al. "Attitude of self-ear cleaning in black Africans: any benefit?" East African Journal of Public Health 6.1 (2009): 143-146.

2. Gadanya M., et al. "Prevalence and attitude of self-ear cleaning with cotton bud among doctors at aminu Kano teaching hospital, North-western Nigeria". Nigerian Journal of Surgical Research 17.2 (2016): 43-47.

3. Kumar B., et al. "Impact of high and low vorticity turbulence on cloud environment mixing and cloud microphysics processes". Atmospheric Chemistry and Physics Discussions 18 (2021): 1-7.

4. Khan NB., et al. "Self-ear cleaning practices and the associated risk of ear injuries and ear-related symptoms in a group of university students". Journal of public health in Africa 8.2 (2017): 149-154.

5. Oladeji SM., et al. "Self-ear cleaning among health workers in Nigeria”. Journal of Dental and Medical Sciences 14 (2015): 122-126.

6. McCarter DF., et al. "Cerumen impaction". American Family Physician 5 (2007): 1523-1528.

7. Olaosun AO. "Self-ear-cleaning among educated young adults in Nigeria". Journal of Family Medicine and Primary Care 1 (2014): 17-21.

8. Al Khabori M., et al. "Magnitude of impacted earwax in Oman, its impact on hearing impairment and economic burden of earwax on health services". Indian Journal of Medical Sciences 61.5 (2007): 278-285.

9. Olajide TG., et al. "Attitude and Awareness of Hazards Associated with Use of Cotton Bud in a Nigerian Community". International Journal of Otolaryngology and Head and Neck Surgery 4 (2015) :248-253.

10. Kumar S and Ahmed S. "Use of cotton buds and its complications". Journal of Surgery (International) 13 (2008): 3.

11. Alshehri AA., et al. "Knowledge, attitudes, and practices of selfear cleaning among medical and non-medical students at King Khalid University, Abha, Saudi Arabia". International Journal of Diabetes in Developing Countries 4.6 (2020): 960-967.
12. Adegbiji WA., et al. "Patterns of Self Ear Cleaning among Otorhinolaryngology Patients in Developing Country". Asian Journal of Science and Technology 9.4 (2018): 1-5.

13. Amutta SB., et al. "Sociodemographic characteristics and prevalence of self-ear cleaning in Sokoto metropolis". International Journal of Otorhinolaryngology and Head and Neck Surgery 2 (2013): 276-279.

14. Burton MJ and Doree C. "Ear drops for the removal of ear wax". Cochrane Database of Systematic Reviews 1 (2009).

Volume 5 Issue 12 December 2021

(C) All rights are reserved by Theophilus 0 Esan., et al. 